\title{
Genetic potential of milk productivity of black-and-white cows depending on selection and management
}

\author{
Alexander Lyubimov, Ekaterina Martynova, Yulia Isupova, Ekaterina Yastrebova, and Elena Achkasova* \\ Izhevsk State Agricultural Academy, 426069 Izhevsk, Russia
}

\begin{abstract}
Currently an increasing attention is paid to breeding animals ensuring the greatest genetic progress of populations in livestock productivity, i.e. stud bulls. Hence, the study of the realization degree of genetic potential of productivity of dairy cattle with different ecogenesis in the conditions of industrial and traditional technology of milk production seems quite relevant. The study revealed that the degree of realization of genetic potential of stud bulls in traditional (tied-up system) and industrial (cubicle system) technology is different.
\end{abstract}

\section{Introduction}

At present, the main objective of dairy cattle industry is to achieve maximum indicators in the production of high-quality products. In order to achieve this objective there is a need to use high-quality animals in terms of their breeding and productive properties. Numerous studies and practical works confirmed that stud bulls significantly affect the genetic effect of animal stock correction: the maximum genetic progress in animal productivity is ensured by correct selection of stud bulls. Domestic black-and-white livestock is improved through animals of the Holstein breed of various selection (Canadian, American, Danish, etc.). However, the use of new genotypes to improve the populations will not give the desired result: it is necessary to optimize the realization of the existing high genetic potential. It is known that it is impossible to achieve the maximum milk productivity without creating optimal conditions for keeping and milking cows. In this regard, there is a need to study the realization of the genetic potential of cows in different conditions, for example, in different maintenance technologies.

A relevant issue in the field of dairy cattle farming is the study of relations between technological elements that ensure intensive production. Technological aspects in general shall be related to the achievements of modern science and shall take into account the best practices of the industry. It was proved that the level of milk productivity is genetically conditioned, but these indicators directly dependent on conditions created in production during the economic use of cows. One of the key aspects of technology is the method of livestock management: the majority of enterprises in Russia use the tied-up method (about $95 \%$ ), since the obvious advantage of this method is the possibility of organizing normal feeding and facilitating the control and service of animals; the other use the cubicle (industrial technology) method (about $5 \%$ ).

Many researchers highlight the significance of such factors as technological aspects of livestock management and use, age and body weight of cows at the first calving, blood system, linear accessory, stud bull. In general, all above factors have direct and significant impact on the realization of the genetic potential of cows.

According to Malyukov M.A., lifetime production of cows to a greater extent depends on paratypic factors about $62 \%$, at the same time technology and age of an animal at first calving has direct influence on lifetime productivity. The study of genotypic factors (about $38 \%$ ) revealed significant influence of a stud bull on lifetime productivity of its daughters [1]. Besides, another important condition for the realization of the genetic potential of cows is the selection of animals of a specific breed with a certain blood rate. For example, the productive longevity of daughters of black-and-white bulls is higher in comparison with Holstein bulls [2].

High importance of the origin of stud bulls is also emphasized by Chetvertakova E.V.: the study of dairy efficiency of daughters of bulls of different pedigree accessory and ecogenesis revealed higher protein content in milk in daughters of mongrel (Holstein) bulls of local selection while the daughters of Danish bulls show higher butterfat percentage and milk yield [3]. Tatueva $\mathrm{O} . \mathrm{V}$. confirmed that the productive progress of the breed in general mainly depends not only on characteristic and genetic heritage of the breed itself, but also on the use of internal genetic groups [4]. The genetic influence of female ancestors from the paternal side on dairy productivity of cows was also confirmed by many experiments and studies [5-8].

In the general assessment of the degree to which genetic and environmental factors affect the genetic

* Corresponding author: achkasovaeva@gmail.com 
potential of cows it was confirmed that the majority of stud bulls have the desired degree of realization of genetic potential, but the imported selection bulls realize their potential to a higher degree [9-11].

Besides, it shall be taken into account that the method of cow management is one of the main technological elements defining the internal technological structure of production, and thus is affects the genetic potential of animals [12]. Science and practice proved the efficiency of industrial technology for milk production in case of tied-up and cubicle management, but many aspects of both methods need to be clarified and adjusted.

The purpose of the study was to analyze the degree of realization of genetic potential of dairy productivity of cattle of various ecogenesis in the conditions of industrial and traditional technology of milk production.

The study on the realization of the genetic potential of dairy productivity of black-and-white cows was carried out in stud farms of Vavozhsky District of the Udmurt Republic: Michurin's Collective Farm (integrated agricultural production company) (cubicle management of cows with equipment (milker robot); tied-up management of cows using Duovak, Delaval equipment), Udmurtia agricultural production cooperative (cubicle management of cows using Europarallel, Stranko and Westfalia equipment and tiedup management using ADM-8 milking units by Westfalia, Stranko), Kolos collective farm (cubicle management using Stranko and Europaralel equipment and tied-up management using Stranko milking equipment).

For reproduction these farms use the seed of stud bulls of black-and-white and Holstein breeds born in Leningrad, Moscow, Udmurt Republic, Germany, the Netherlands, Denmark and Canada. The assessment included stud bulls having lactic daughters for the period of study. The distribution of stud bulls by selection was carried out according to the country and region of their origin (Domestic - Russia, Foreign - Canada, Germany, the Netherlands). Thus, two groups of stud bulls of different selection were formed. Taking into account the region and the country of origin, each selection was divided into groups: Domestic - Moscow, Leningrad, Udmurt; Foreign - Canada and Europe (Germany, the Netherlands, Denmark).

The genetic potential of stud bulls was calculated on the basis of productivity according to the highest lactation of female ancestors as the parent bull index (PBI) by the formula:

$$
\mathrm{PBI}=(2 \mathrm{M}+\mathrm{MM}+\mathrm{MF}) / 4,
$$

where $\mathrm{M}$ - productivity of the bull's mother;

MM - productivity of the mother of the bull's mother;

MF - productivity of the bull's father's mother.

The degree of realization of the genetic potential was determined by the formula:

$$
\mathrm{RGP}=\mathrm{y} / \mathrm{PBI} \times 100 \%
$$

where RGP - realization of genetic potential;

$\mathrm{Y}$ - productivity of daughters by the highest lactation;

PBI - parent bull index.
All digital material of the study was biometrically processed on a personal computer using Microsoft Excel according to N.A. Khodinsky's method (1969).

\section{Results and discussion}

The study of the level of dairy productivity of black-andwhite cows of different ecogenes kept in breeding farms of the republic under different production technologies revealed that the milk yield of cows of the Moscow selection under industrial technology on average made $7809.4 \mathrm{~kg}$, which is higher than the traditional technology by $374.8 \mathrm{~kg}$ or $5.0 \%$ (Tables 1 and 2).

The mass fraction of fat in milk was higher in the group under traditional management technology and amounted to $4.04 \%$.

As for Leningrad selection, the highest milk yield in industrial technology amounted to $7543.4 \mathrm{~kg}$ with $3.99 \%$ fat content in milk, which is higher in comparison with traditional processing technology by $603.7 \mathrm{~kg}$ or $8.7 \%$ and by $0.08 \%$, respectively, but the difference in groups is not reliable. As for Udmurt selection, the weight and fat content of milk according to the highest milk yield are higher in industrial technology compared to the traditional technology by $516.9 \mathrm{~kg}$ or $7.9 \%$ respectively, and made $7051.6 \mathrm{~kg}$ and by $0.01 \%$ and made $3.79 \%$.

Under industrial technology the daughters of stud bulls of Holstein breed of the Moscow selection have higher milk yield and fat content in milk according to the highest lactation compared to traditional technology. Thus, the weight in industrial technology made on average $7682.8 \mathrm{~kg}$ in terms of selection, which is higher in comparison with tied-up technology by $241.2 \mathrm{~kg}$ or $3.2 \%$, in terms of fat content in milk - by $0.08 \%$, but the difference in groups is not reliable.

As for Canadian selection, the milk yield according to the highest lactation in industrial technology made $6901.7 \mathrm{~kg}$, which is higher in comparison with traditional technology by $133.0 \mathrm{~kg}$ or $2.0 \%$. The same situation concerns protein content in milk, but fat content in milk was higher in traditional technology and made $3.90 \%$.

Tables 3 and 4 show the degree of realization of genetic potential of stud bulls of black-and-white and Holstein breeds on average by selection depending on management technology.

Under traditional technology (Table 3), the degree of realization of genetic potential according to milk yield of stud bulls of black-and-white breed varied from $63.6 \%$ to $81.6 \%$. As for Moscow selection the RGP level according to milk yield made $81.6 \%$, which is higher in comparison with Leningrad selection by $18.3 \%(\mathrm{p} \leq 0.01)$ and with Udmurt - by $9.9 \%$.

Concerning fat, the RGP level is the highest in the group of stud bulls of Leningrad selection and makes $98.2 \%$, which is reliably higher in comparison with stud bulls of black-and-white breed of Udmurt ecogenesis by $5.3 \%(\mathrm{p} \leq 0.05)$.

The stud bulls of Moscow selection have the smallest level of realization of genetic potential on protein - 
$96.4 \%$, which is lower in comparison with Leningrad selection by $4.6 \%(\mathrm{p} \leq 0.01)$ and Udmurt selection by $8.7 \%(\mathrm{p} \leq 0.001)$. At the same time in terms of the RGP level on protein the stud bulls of Udmurt ecogenesis reliably surpass the stud bulls of Leningrad selection by $4.1 \%(\mathrm{p} \leq 0.05)$.

Table 1. Milk productivity of cows of different selection under traditional (tied-up) technology

\begin{tabular}{|c|c|c|c|c|c|c|}
\hline \multirow{2}{*}{ Selection } & \multicolumn{7}{|c|}{ Milk productivity } \\
\cline { 2 - 7 } & \multicolumn{7}{|c|}{ according to 1 lactation } & \multicolumn{2}{c|}{ according to the highest lactation (max lactation) } \\
\cline { 2 - 7 } & Milk yield, kg & $\begin{array}{c}\text { Fat mass } \\
\text { fraction, \% }\end{array}$ & $\begin{array}{c}\text { Protein mass } \\
\text { fraction, } \%\end{array}$ & Milk yield, kg & $\begin{array}{c}\text { Fat mass } \\
\text { fraction, } \%\end{array}$ & $\begin{array}{c}\text { Protein mass } \\
\text { fraction, \% }\end{array}$ \\
\hline \multicolumn{7}{|c|}{ Black-and-white breed } \\
\hline Moscow & $\begin{array}{c}5770.6 \pm \\
179.2\end{array}$ & $\begin{array}{c}3.70 \pm \\
0.05\end{array}$ & $3.13 \pm 0.02$ & $7434.6 \pm 296.6$ & $4.04 \pm 0.05$ & $3.22 \pm 0.01$ \\
\hline Leningrad & $6192.7 \pm 205.4$ & $3.78 \pm 0.05$ & $3.19 \pm 0.02$ & $6939.7 \pm 259.3$ & $3.91 \pm 0.09$ & $3.21 \pm 0.01$ \\
\hline Udmurt & $6411.1 \pm 181.3$ & $3.74 \pm 0.11$ & $3.21 \pm 0.02$ & $6534.7 \pm 207.7$ & $3.78 \pm 0.13$ & $3.18 \pm 0.03$ \\
\hline Moscow & $6512.7 \pm 165.8$ & $3.78 \pm 0.05$ & $3.18 \pm 0.02$ & $7441.6 \pm 312.1$ & $3.90 \pm 0.10$ & $3.22 \pm 0.06$ \\
\hline European & $6861.3 \pm 161.4$ & $3.78 \pm 0.05$ & $3.22 \pm 0.01$ & $7086.1 \pm 253.9$ & $3.83 \pm 0.05$ & $3.22 \pm 0.01$ \\
\hline Canadian & $6732.5 \pm 113.9$ & $3.88 \pm 0.04$ & $3.20 \pm 0.01$ & $6768.7 \pm 717.0$ & $3.90 \pm 0.12$ & $3.20 \pm 0.01$ \\
\hline
\end{tabular}

Table 2. Milk productivity of cows of different selection under industrial (cubicle) technology

\begin{tabular}{|c|c|c|c|c|c|c|}
\hline \multirow{2}{*}{ Selection } & \multicolumn{5}{|c|}{ Milk productivity } \\
\cline { 2 - 7 } & \multicolumn{7}{|c|}{ according to 1 lactation } & \multicolumn{3}{c|}{ according to 1 lactation } \\
\cline { 2 - 7 } & Milk yield, kg & $\begin{array}{c}\text { Fat mass } \\
\text { fraction, \% }\end{array}$ & $\begin{array}{c}\text { Protein mass } \\
\text { fraction, \% }\end{array}$ & Milk yield, kg & $\begin{array}{c}\text { Fat mass } \\
\text { fraction, \% }\end{array}$ & $\begin{array}{c}\text { Protein mass } \\
\text { fraction, \% }\end{array}$ \\
\hline \multicolumn{7}{|c|}{ Black-and-white breed } \\
\hline Moscow & $5995.2 \pm 191.6$ & $3.79 \pm 0.03$ & $\begin{array}{c}3.18 \pm \\
0.01\end{array}$ & $7809.4 \pm 138.7$ & $3.95 \pm 0.02$ & $3.22 \pm 0.01$ \\
\hline Leningrad & $6051.1 \pm 193.8$ & $3.78 \pm 0.04$ & $3.17 \pm 0.01$ & $7543.4 \pm 182.4$ & $3.99 \pm 0.05$ & $3.21 \pm 0.01$ \\
\hline Udmurt & $6624.3 \pm 135.1$ & $3.66 \pm 0.06$ & $3.19 \pm 0.01$ & $7051.6 \pm 181.3$ & $3.79 \pm 0.07$ & $3.17 \pm 0.01$ \\
\hline \multicolumn{7}{|c|}{ Holstein breed } \\
\hline Moscow & $6473.0 \pm 163.9$ & $3.81 \pm 0.04$ & $3.19 \pm 0.01$ & $7682.8 \pm 283.6$ & $3.98 \pm 0.07$ & $3.18 \pm 0.03$ \\
\hline European & $6775.3 \pm 153.6$ & $3.73 \pm 0.06$ & $3.21 \pm 0.01$ & $7170.6 \pm 286.3$ & $3.70 \pm 0.07$ & $3.21 \pm 0.01$ \\
\hline Canadian & $6821.4 \pm 121.3$ & $3.65 \pm 0.05$ & $3.17 \pm 0.05$ & $6901.7 \pm 357.3$ & $3.67 \pm 0.13$ & $3.22 \pm 0.02$ \\
\hline
\end{tabular}

Table 3. Degree of realization of genetic potential of stud bulls of different selection under traditional (tied-up) technology

\begin{tabular}{|c|c|c|c|c|}
\hline \multirow[b]{2}{*}{ Selection } & \multirow{2}{*}{$\begin{array}{c}\text { Number of } \\
\text { bulls }\end{array}$} & \multicolumn{3}{|c|}{ Realization of genetic potential } \\
\hline & & $\begin{array}{l}\text { according to milk yield, } \\
\text { kg }\end{array}$ & $\begin{array}{l}\text { according to fat } \\
\text { mass fraction, } \%\end{array}$ & $\begin{array}{c}\text { according to protein } \\
\text { mass fraction, } \%\end{array}$ \\
\hline \multicolumn{5}{|c|}{ Black-and-white breed } \\
\hline Moscow & 3 & $81.6 \pm 4.5$ & $96.6 \pm 1.9$ & $96.4 \pm 0.3^{* * *}$ \\
\hline Leningrad & 8 & $63.6 \pm 2.5^{* *}$ & $98.2 \pm 1.8$ & $101.0 \pm 1.2^{*}$ \\
\hline Udmurt & 4 & $71.7 \pm 2.7$ & $92.9 \pm 1.7^{*}$ & $105.1 \pm 0.9$ \\
\hline \multicolumn{5}{|c|}{ Holstein breed } \\
\hline Moscow & 5 & $72.1 \pm 3.1^{* * *}$ & $88.8 \pm 3.4$ & $95.5 \pm 2.3^{*}$ \\
\hline European & 5 & $55.5 \pm 4.6^{* * * *}$ & $93.8 \pm 4.6$ & $98.9 \pm 3.4$ \\
\hline Canadian & 3 & $46.2 \pm 2.2$ & $86.7 \pm 3.4$ & $100.7 \pm 0.9$ \\
\hline
\end{tabular}

Note: $*-\mathrm{p} \leq 0.05 ; * *-\mathrm{p} \leq 0.01 ; * * *-\mathrm{p} \leq 0.001$.

Table 4 Degree of realization of genetic potential of stud bulls of different selection under industrial (cubicle) technology

\begin{tabular}{|c|c|c|c|c|}
\hline \multirow[b]{2}{*}{ Selection } & \multirow[b]{2}{*}{ Number of bulls } & \multicolumn{3}{|c|}{ Realization of genetic pot } \\
\hline & & $\begin{array}{l}\text { according to milk yield, } \\
\text { kg }\end{array}$ & $\begin{array}{l}\text { according to fat } \\
\text { mass fraction, } \%\end{array}$ & $\begin{array}{l}\text { according to protein } \\
\text { mass fraction, } \%\end{array}$ \\
\hline \multicolumn{5}{|c|}{ Black-and-white breed } \\
\hline Moscow & 3 & $85.6 \pm 4.6$ & $94.6 \pm 3.2$ & $96.1 \pm 1.1^{* *}$ \\
\hline Leningrad & 8 & $69.0 \pm 2.6^{* *}$ & $99.6 \pm 2.0$ & $100.2 \pm 1.1^{*}$ \\
\hline Udmurt & 4 & $76.9 \pm 2.6$ & $91.9 \pm 2.6^{*}$ & $104.5 \pm 1.1$ \\
\hline \multicolumn{5}{|c|}{ Holstein breed } \\
\hline Moscow & 5 & $74.4 \pm 1.9$ & $88.4 \pm 2.4$ & $99.2 \pm 0.9$ \\
\hline European & 5 & $57.7 \pm 3.9^{* * *}$ & $86.7 \pm 2.9$ & $94.8 \pm 2.3$ \\
\hline Canadian & 3 & $47.1 \pm 2.9^{* * * *}$ & $88.3 \pm 4.4$ & $99.4 \pm 0.9$ \\
\hline
\end{tabular}

Note: * $-\mathrm{P} \leq 0.05 ; * *-\mathrm{P} \leq 0.01 ; * * *-\mathrm{P} \leq 0.001$. 
In the group of stud bulls of Holstein breed of various ecogenesis in the conditions of traditional technology the stud bulls of Moscow selection have high RGP level in terms of milk yield $-72.1 \%$, which is higher in comparison with European selection by $16.6 \%$ $(\mathrm{p} \leq 0.01)$ and Canadian - by $25.9 \%(\mathrm{p} \leq 0.01)$.

In terms of fat the RGP level of the stud bulls of Holstein breed varies from $86.7 \%$ (Moscow selection) to $93.8 \%$ (Canadian selection), there are no reliable differences in groups. The stud bulls of Moscow selection have high RGP level on protein - $100.7 \%$, which is higher in comparison with the stud bulls of European ecogenesis by $5.2 \%(\mathrm{p} \leq 0.05)$ and Canadian by $1.8 \%$.

In the analysis of the level of realization of genetic potential of the stud bulls of Domestic selection it shall be noted that the stud bulls of Holstein breed of Moscow ecogenesis reliably surpass the stud bulls of Leningrad ecogenesis in the RGP level on milk yield by $8.5 \%$ $(p \leq 0.05)$. Besides, the stud bulls of black-and-white breed of Moscow, Leningrad and Udmurt selection have higher RGP level on fat in comparison with Moscow Holstein breed by $9.9 \%(\mathrm{p} \leq 0.05), 11.5 \%(\mathrm{p} \leq 0.01)$ and $6.2 \%(\mathrm{p} \leq 0.05)$ respectively.

The analysis of the level of realization of genetic potential of the stud bulls of Foreign selection on milk yield, fat and protein did not reveal reliable differences, but the RGP level on milk yield and fat is higher for the stud bulls of European selection, and the RGP level on protein is higher for Canadian selection.

Under industrial technology of management (Table 4) the level of realization of genetic potential on milk yield of the stud bulls of black-and-white breed of Moscow selection varied from 69.0 (Leningrad selection) to $85.6 \%$ (Moscow selection), at the same time the difference in groups is reliable $(p \leq 0.01)$. The RGP level on fat is the highest in the group of stud bulls of Leningrad ecogenesis by $99.6 \%$, which is higher in comparison with Moscow selection by $5.0 \%$ and Udmurt - by $7.7 \%(\mathrm{p} \leq 0.05)$.

The stud bulls of Udmurt selection are characterized by high RGP level on protein by $104.5 \%$, which is higher in comparison with Moscow selection by $8.4 \%$ $(\mathrm{p} \leq 0.01)$ and Leningrad selection by $4.3 \%(\mathrm{p} \leq 0.05)$.

In the group of the stud bulls of Holstein breed the level of realization of genetic potential on milk yield is the highest for Moscow selection - $74.4 \%$, which is higher in comparison with the stud bulls of European selection by $16.7 \%(\mathrm{p} \leq 0.01)$ and Canadian - by $27.3 \%$ $(\mathrm{p} \leq 0.001)$.

The level of realization of genetic potential in terms of protein of the stud bulls of Holstein breed is at the same level - 86.7-88.4 \% and there are no reliable differences between bulls of different ecogenesis. The same situation is observed for the RGP level of protein from $94.8 \%$ (European selection) to $99.4 \%$ (Moscow selection).

\section{Conclusion}

The level of realization of genetic potential regarding milk yield of stud bulls of black-and-white and Holstein breeds of various ecogenesis is higher in the conditions of industrial technology of their management. The level of RGP in mass fat fraction of stud bulls of black-andwhite breed of Moscow and Udmurt selection, as well as stud bulls of Holstein breed of European and Canadian selection is higher in the conditions of traditional technology.

The RGP level in mass protein fraction of stud bulls of black-and-white breed of various ecogenesis and stud bulls of Holstein breed of Moscow and European selection is higher in the conditions of traditional technology.

\section{References}

1. M.A. Malyukova, Niva Volga, 3, 56-59 (2012)

2. S.V. Titova, Bull. of the Mari State Univer., 2, 52-53 (2015)

3. E.V. Chetvertakova, Bull. of Omsk State Agrar. Univer., 1, 192-197 (2016)

4. O.V. Tatueva, D.N. Koltsov, Int. res. J., 1(11-5), 47-52 (2016)

5. L.Y. Bolotova, R.P. Karagod, V.G. Prokop'ev, Eastern Europ. Sci. J., 5, 38-45 (2014)

6. M. Smirnova, S. Safronov, S. Doroshuk, Dairy and beef cattle breeding, 8, 15-17 (2013)

7. S. Karamaev, Ye. Kitaev, N. Soboleva, Dairy and beef cattle breeding, 8, 14-16 (2010)

8. A.V. Randelin et al., Lithuania agricultural university lectures: science and higher vocational education, 2, 207-212 (2018)

9. N.M. Kosyachenko et al., Dairy and beef cattle breeding, 8, 13-16 (2018)

10. F.M. Tokova, M.B. Ulimbashev, Bull. of Altai State Agrar. Univer., 3, 108-111 (2016)

11. L.I. Kibkalo et al., Bull. of the Kursk State Agricult. Acad., 3, (2015)

12. A.I. Lyubimov et al., The genetic potential of cattle of various ecogenesis and its implementation in the conditions of industrial and traditional production (2018) 